Copyright (C) 2018 by Academic Publishing House Researcher

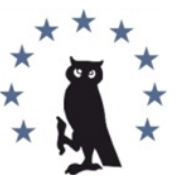

Published in the Russian Federation

European Researcher. Series A

Has been issued since 2010.

ISSN 2219-8229

E-ISSN 2224-0136

2018, 9(3): 203-211

DOI: $10.13187 /$ er.2018.3.203

www.erjournal.ru

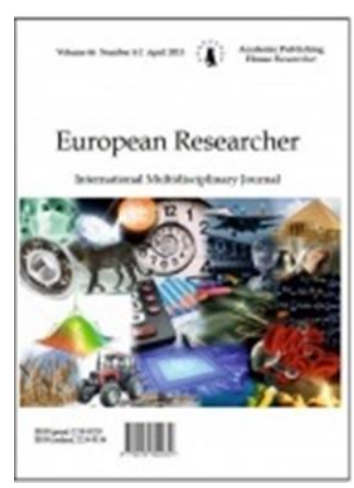

\title{
The Police Assistance during the Enforcement Action
}

\author{
Vladimir Boranijašević ${ }^{a},{ }^{*}$, Slobodanka Kovačević-Perić a \\ a University of Priština with Temporary Headquarters in Kosovska Mitrovica, \\ the Republic of Serbia
}

\begin{abstract}
The enforcement action represents the stadium of the enforcement procedure in which the claims of the executive creditor are finally settled forcedly. Depending on the kind of claims which are settled, the enforcement is implemented by taking certain actions, or by implementing special methods for enforcement action.

In certain situations the police assistance is necessary during the enforcement action. The public executive officer, as an institution implementing the enforcement, whose authority is the enforcement action in most of the executive legal matters, is authorized to ask for the police help, in accordance with the regulations of the Law on the Police. In cases when resistance during the enforcement action is anticipated, when some resistance has already been given during the previous attempt of the enforcement action, or if during undertaking executive actions there appear a need for elimination of a life or health danger for people or danger for property, there is a need for the police assistance during the enforcement action. The public executive officer is then authorized to request the police help, according to the legally regulated procedure.

Situations in which there is a need for the police assistance during the enforcement action are analyzed in the paper. It is also pointed to the regulations connected with the procedure of request for the police help, and the legal rules about the urgent police help are analyzed. The authors also analyze the measures that the police undertake in the scopes of their authority in order to take the enforcement action, as well as the possibility of pausing the enforcement action on the request of the police when violation of public order or some broader violence is anticipated.

Keywords: the enforcement action, the public executive officer, the police, the police assistance.

\section{Introduction}

Bringing a verdict in the Civil Proceedings, by which a defendant is ordered to perform a certain action, does not necessarily mean that the defendant will act according to the court order contained in the verdict and that the prosecutor will definitely be offered the legal protection. When the litigation court brings a condemnatory verdict for action and orders the defendant to perform a monetary or non-monetary action, the defendant is obliged to perform the ordered action in the voluntary deadline period. It is a deadline for voluntary performing the debt action, and it is a total of 15 days, while special regulations can order a shorter deadline (Zakon o

\footnotetext{
${ }^{*}$ Corresponding author

E-mail addresses: vladimir.boranijasevic@pr.ac.rs (V. Boranijašević)
} 
parničnom postupku, 2011: art. 345. par. 2). If the deadline period is over, without performing of the action by the defendant, there is a need for a forced execution.

When there is a need for a forced execution, the executive creditor has a right to initiate the enforcement action in order to settle their claims. The enforcement action represents a special civil court procedure in which the executive creditor's claims are settled forcedly. The rules according to which to act in the enforcement action are regulated by the Law on Enforcement and Security of the Republic of Serbia (Zakon o izvršenju i obezbeđenju, 2015).

In the stage of the enforcement execution the final goal of the enforcement action is realized, since in this phase of the procedure the executive creditor's claims are settled forcedly. Settlement of the executive creditor's claims is achieved by implementation of different enforcement instruments on different subjects of enforcement, depending on the kind of claims that are settled, and in the scopes of the enforcement decision which represents a basis for the enforcement execution.

It is exactly during the enforcement execution when in certain circumstances the police assistance is necessary in order for the enforcement action to be implemented completely and for the executive creditor's claims to be finally settled. In cases when during the enforcement execution resistance has already occurred, or when resistance is anticipated, or when violation of public order or some broader violence is anticipated, the public executive officer who implements the enforcement has a right to request the police assistance, according to special rules regulated by law.

\section{Discussion}

\section{The Stage of the Enforcement Action}

Two stages of the procedure comprise the whole of the enforcement procedure. The enforcement procedure is implemented through the stage of the enforcement permission and stage of the enforcement action, in which different process goals are achieved (Stanković, Boranijašević, 2017: 109; Stanković, 2007: 159).

In the stage of the enforcement permission, the enforcement court acts in accordance with the suggestion for enforcement that has been initiated by the executive creditor by which they have requested forced settlement of their claims. In case the request of the executive creditor for forced settlement is grounded, and court has determined this fact in this stage of the procedure, court brings a decision on enforcement and orders the enforcement by a certain enforcement instrument on a concrete subject of enforcement or the whole property of the executive debtor.

The stage of the enforcement action is a stage of the procedure that happens after the decision on enforcement has been brought. This stage of the procedure does not happen in accordance with some uniform rules, since the very stage of the enforcement action depends on the enforcement instrument and subject of enforcement, the kind of claims that are settled, and also on the fact whether the enforcement is executed by the court or public executive officer.

The enforcement is executed by either the court or public executive officer. Public executive officers, at the time called only "executive officers", have been introduced into our legal system in 2011 when the first Law on Enforcement and Security has been introduced in the Republic of Serbia (Zakon o izvršenju i obezbeđenju, 2011). Public executive officers were then delegated certain public authorization and court function was transferred to them concerning a specific special enforcement procedure (Boranijašević, 2017: 16). According to the valid legal norms at the time, whether the enforcement was going to be executed by the court or public (at the time private) executive officer depended on the will of the executive creditor, since they were obliged to note whether the enforcement was going to be executed by the court or private executive officer in the very decision on enforcement (LES 2011: art. 35. par. 6), except in the enforcement process matters that were in the exclusive authority of court at the time as well.

The new, valid, LES strictly regulates in which enforcement process matters the enforcement is executed by court and in which ones by the public executive officer. Court is exclusively in charge of the enforcement action by a joint sale of the real estate and movable property, of execution of the obligation to act, not to act or to endure, of the enforcement action in family-legal executive matters and the enforcement action for the sake of returning an employee to work (LES: art. 4. par. 1). On the other hand, public executive officers are exclusively in charge of the enforcement action in enforcement procedures on the ground of other executive documents, an authentic document, in the procedure of counter-execution and procedure of pronouncing court penalties. 
It is evident that with new legal solutions the legislator has quit the parallel system of the enforcement action and the system of alternative authority in the enforcement action and whether the enforcement is going to be executed by the court or public executive does not depend on the will of the executive creditor any longer (Boranijašević, 2017: 16). From the aspect of division of authorization for the enforcement action, and the fact that the public executive officer is in charge of the most enforcement process matters, the legislator talks about the request of the public executive officer for the police assistance. However, court also has this authorization if in legal matters which are in its exclusive authorization appears a need for the police assistance.

\section{The Police Assistance during the Enforcement Action}

In normal, factual, circumstances the enforcement action should be completed in a peaceful manner, without interference of persons who do not participate in the procedure, without danger for property or lives of people that the procedure does not relate to, and without violation of public order and some broader violence. In situations regulated by law, both the court and public executives during the enforcement action have to act in accordance with the regulations of law concerning the way and time of the enforcement action and they must not overcome their authorization. In regular life circumstances, as a rule, the police assistance during the enforcement action is not necessary.

However, if we take into account the social-economic conditions that we live in, a hard financial situation for most of population, and not much "affection" towards public executive officers $^{*}$ situations in which the police assistance during the enforcement action is more than necessary are very common. The help of the police is necessary not only in the stage of the enforcement action, but also in some circumstances during the very enforcement procedure when there is a need for issuing a wanted list for the executive debtor who is on the run, or a need for publishing a post by the order of the public executive officer in order to find vehicles or other subjects of enforcement. In this case the police acts according to the court order to issue a wanted list, or publish a post, which represents a significant novelty in domestic law (Keča, Knežević, 2017: 561; Stanković, Boranijašević, 2017: 172).

In the scopes of their authorization, the police protect, provide and improve the security of citizens and property, while the role of the police, their tasks and organization represent a subject of regulations of the Law on the Police of the Republic of Serbia (Zakon o policiji, 2016). The LP, in the regulations from the article 47, regulates the police measures and actions that police officers in the status of authorized public officials apply while performing their police duties. One of the measures and actions is the "police assistance in enforcements and procedures of out-of-court settlements". The general regulation of this law states that "if during the enforcement of the decision of a state authority or a legal entity of an individual with public authorizations, or an authorized legal entity or an individual in a procedure of out-of-court settlement, some resistance is anticipated, the police will offer assistance to these authorities and individuals in order to enable a secure enforcement implementation, with their written request". It is indisputable that this assistance refers to both the court and public executive officer, as an individual with public authorizations, when the police assistance is necessary for the sake of a secure enforcement action. The essence of the police assistance, as a kind of a police job, is to enable the court or public executive officer implementation of a certain official act, applying the police authorizations, in cases resistance of people to implementation of that act or enforcement of a decision is anticipated (Posilović et al., 2014: 106).

\section{The Request of the Public Executive Officer}

The police assistance cannot be acquired without the procedure which is regulated by both the LP and LES. An important characteristic of providing the police assistance is that it is provided on the request of the court or public executive officer, it is provided according to a special

\footnotetext{
* See the text: „Ни полиција није могла да га спречи: син дужника штанглом претукао извршитеља“ „The police could not even stop him: the son of a debtor beat the public executive officer with a bar“: https://www.srbijadanas.net/ni-policija-nije-mogla-da-ga-spreci-sin-duznika-stanglom-pretukaoizvrsitelja/, accessed on $6^{\text {th }}$ May 2018.
} 
procedure andthe authorizations in providing the police assistance are regulated by the law. (Stanković et al., 2018: 587).

The public executive officer will require the police assistance in case some resistance has already been offered during the enforcement action or resistance is anticipated. For instance, in the enforcement procedure on real estate or movable property, there is a possibility of the executive debtor not allowing the public executive officer to make a list of items on which to implement the enforcement while threatening the public executive officer and other present people, endangering the security and lives of the people; in the procedure for emptying and handing over the real estate, the executive debtor may refuse to leave the real estate or may interfere with removal of furniture from the mentioned real estate etc.

The LES differentiates between two situations in which the public executive officer can request the police assistance. In the first one the police assistance is needed for the sake of implementation of enforcement when resistance has already been given during the enforcement action or is anticipated, while the other relates to the cases when urgent police assistance is necessary.

In the first situation the public executive officer is obliged to direct a request for the police assistance to the authorized organizational police unit before implementation of enforcement actions. Namely, when the public executive officer knows that in the enforcement procedure that they have been undertaking resistance has already occurred, there are grounds for them to request the police assistance anticipating for the resistance to occur again. On the other hand, even though there has not been any resistance, since no enforcement actions have been undertaken, the public executive officer may assess that in some cases resistance can be anticipated. In that case the public executive officer is obliged to hand in a submission, in writing, in order to request the police assistance. The public executive officer is obliged to request in writing the police assistance during the enforcement action from the authorized organizational police unit at least five days before the enforcement action (LES: art. 143. par. 1). Unlike the LES, the LP states that the request is directed to the locally authorized organizational police unit at least five week days before the day of the enforcement action (LP: art. 54. par. 1). Therefore the regulations of these two laws concerning the deadline have not been harmonized.

When the legislator mentions the written form, they do not define the contents of the submission that contains the request for the police assistance that the public executive officer initiates. It is logical that the submission should contain the name of the locally authorized organizational police unit, the identification data of the parties in the enforcement procedure and of the public executive officer, the time and place of the implementation of the action enforcement action, the request for the police assistance and the signature of the public executive officer. The very request of the public executive officer has to be explained, i.e. the public executive officer is obliged to state in the submission what the police assistance is needed for. The explanation of the request itself has to be complete and detailed, so that out of these details the authorized organizational police unit could conclude that the police assistance is necessary. On the other hand, every unjustified request for the police assistance leads to inadequate usage of police resources, unnecessary costs of the enforcement procedure and misuse of the public executive officer's authorizations. The LP is more detailed concerning the contents of the submission, so it states that besides noting the reasons for the police assistance and the copy of the decision that is to be implemented, it is necessary to enclose the evidence that the enforcement has been attempted without the police assistance and evidence of engaging the following services necessary for the enforcement (LP: art. 54. par. 2).

With the submission which contains the request for the police assistance, the public executive officer is obliged to enclose the copy of the decision on enforcement which is a basis for the enforcement action. The decision on enforcement is necessary to be enclosed because the authorized organizational police unit this way informs itself about the court decision which offers the justification of the enforcement action. On the other hand, in the decision on enforcement the concrete locally authorized public executive officer for the enforcement action is defined, so in this way the public executive officer proves their authorization to request the police assistance during the enforcement action.

The second situation in which the public executive officer can claim the police assistance during the enforcement action is specific and the above described rules for requesting the police 
assistance are deviated from. More accurately, in certain situations the police assistance can be claimed orally. In cases when the police assistance is necessary in order to eliminate life or health danger or danger for larger property (LES: art. 143. par. 2) there is an urgent case in which the police assistance can be requested orally. For instance, the executive debtor is holding a bomb in their hand and threatening that they will activate it and therefore endanger lives of people and property; the executive creditor is threatening to use firearm; the executive creditor, being under influence of alcohol or drugs, is threatening to pour gasoline on the house and put the house and the people inside on fire, etc. (Stanković, Palačković, Trešnjev, 2018: 587; Stanković, Boranijašević: 2017: 171).* Then, the public executive officer orally, urgently, claims for the assistance from the authorized organizational police unit. An urgent case and urgent need for the police assistance does not deprive the public executive officer of obligation to deliver a written request for the police assistance to the authorized organizational police unit. They are obliged to deliver the request within 48 hours (LES: art. 143, par. 2; LP : art. 54. par. 3). The need for the written request to be delivered is justified, since this way the urgent engagement of the police is justified, as well as the costs that the police action causes in the enforcement procedure.

\section{The Police Action}

After receiving the submission from the public executive officer which contains a request for the police assistance, the manager of the authorized organizational police unit brings a decision on providing the police assistance during the enforcement action. If, concerning the reasons mentioned in the submission of the public executive officer, the manager of the authorized organizational police unit determines that the police assistance is necessary during the enforcement action, they bring a decision on engagement of the police during the enforcement action in the concrete executive legal matter.

The chief of a police department, or of a police station, decides on the engagement of the police, as well as on the way and scopes of the assistance during the enforcement action. The manager of the authorized organizational police unit promptly informs the public executive officer or court about the brought decision and the way and scopes of the police assistance to be provided.

Before the very police assistance during the enforcement action, the police are obliged to immediately perform all the security checks. On the other hand, the police check the persons that the enforcement is related to in the data base and records in the Ministry of Internal Affairs (LP: art. 55. par. 1). The police are also obliged to temporarily take away the legal weapons and other objects convenient for endangering security before the enforcement if they determine that the person the enforcement is related to (the executive debtor) or some other person who is a member of the household legally possesses weapon, and to undertake other legally regulated actions that provide conditions for a secure enforcement action. The police officer is obliged to return the taken away weapons or other objects within 48 hours from the moment of completion of the action, except in cases when a person does not fulfill the criteria for legal keeping of weapons according to the regulations on weapons and ammunition.

According to the LES, before the very implementation of the action, the police is obliged to warn the executive debtor and other present people that the coercion instruments are going to be used if they interfere with or prevent the implementation of the action, and actions that can be undertaken according to law are also going to be undertaken during the enforcement action, by their own initiative or on the request of the public executive officer (LES: art. 144. par. 2). This legal regulation is in accordance with the regulation from the article 31 of the Rulebook on the Way of Conduct of Police Affairs (Pravilnik o načinu obavljanja..., 2007. Hereinafter: RPA) which states that a police officer will use the coercion instruments if conditions for their use are fulfilled and if

\footnotetext{
* See also: the text named: „Драма у Лебану: Полио се бензином и чека извршитеља, око њега живи зид“ („Drama in Lebane: Poured gasoline on himself and is waiting for the executive officer, a live wall around him“), available at: http://jugmedia.rs/drama-lebanu-polio-se-benzinom-ceka-izvrsitelja-oko-njegazivi-zid/, accessed on $6^{\text {th }}$ May 2018; the text named:„Да би спречиле исељење, мајка и ћерка напале полицију и извршитеље“ ("In order to stop the eviction, the mother and daughter attacked the police and executive officers"), available on: http://nadlanu.com/145930/da-bi-sprecile-iseljenje-majka-i-cerka-napalepoliciju-i-izvrsitelje/, accessed on $6^{\text {th }}$ May 2018.
} 
moving away the person who is preventing or interfering with the enforcement cannot be provided by mere implementation of the police authority - warning and order. Therefore, before the implementation of the coercion instruments for the sake of unhindered implementation of the enforcement, a police officer is obliged to use their authorization in order to warn the executive debtor and other persons which potentially can interfere with the enforcement action that they will use the coercion instruments and order them to leave the premises or building in order to implement the action. In case the executive debtor and other people do not act according to the police officer's warning and order, they can use the coercion instruments for the sake of unhindered implementation of the enforcement. In case the conditions for the use of the coercion instruments are not fulfilled, the police officer informs the court or public executive officer and their competent manager about this.

A situation in which during the enforcement action disturbance of public order or some broader violence is expected is also possible. In a situation like this, after they have received the court or public executive officer's claims for the police assistance, and upon the reasons mentioned in it they determine that disturbance of public order or broader violence could be anticipated, the manager of the authorized organizational police unit has specific authorizations. Namely, they can request from the court or public executive officer in writing to pause the enforcement action (Stanković, Boranijašević, 2017: 171) 48 hours at the latest before the enforcement action starts. This deadline is justified since it is necessary for the court and public executive officer to delay the already scheduled enforcement action about which they have informed the police in writing and asked for their assistance. The manager of the authorized organizational police unit will request a pause in the enforcement action in order to take the measures and actions necessary for a secure enforcement action, concerning the fact that disturbance of public order or broader violence is anticipated. Since there is a pause in the enforcement action, the public executive officer and manager of the authorized organizational police unit are obliged to define together the date for implementation of the enforcement action within the deadline not longer than ten days (LES: art. 144. par. 3).

As the police assistance is not without order, the police make a plan of assistance. That plan is approved by the chief of the police department, or a commander of the police station in charge in the area of providing assistance (RPA: art. 30).

Police officers while providing assistance in the enforcement action have to act according to law. While providing the assistance, police officers may use police authorizations regulated by law exclusively for the sake of protection of lives, human and minority rights and freedom of citizens and property, protection of public order, as well as prevention and detection of criminal acts and offences, and data collection concerning those acts and their perpetrators. They can use only those coercion instruments and in the amount necessary to reject the attack on them, the public executive officer or a third party, or to overcome the resistance that disables the enforcement action (RPA: art. 32).

During the assistance, police officers have to act according to the regulations of the Code of Police Ethics (Kodeks policijske etike, 2017) and the Rulebook on Technical Characteristics and the Way of Usage of Coercion Instruments (Pravilnik o tehničkim..., 2007). Police officers are obliged to act in a legal, professional, just and humane way, acting in accordance with the rules and basic principles of conduct regulated by the Code. For instance, police officers are obliged to respect the integrity of an individual during the action, to protect the reputation and integrity of police officers, to protect official duty and official data, to act professionally and independently etc. On the other hand, applying the principle that a preventive action has the advantage over a repressive action, since the warning and order have not been successful, while using coercion instruments in that situation, police officers use the coercion instrument that enables a successful completion of the police work with the fewest consequences for the person that the coercion instrument is used on (RCI: art. 2). The RCI regulates certain coercion instruments that police officers can use (physical force, a police stick, binding instruments etc.), but also the way of usage of those instruments (LP: art. 110-128; RCI: art. 4 and art. 6-9).

During the enforcement action the most frequently used coercion instruments are physical force and binding instruments, since persons giving resistance to the process of enforcement or persons who are to be held or caught could be restrained by these instruments. Their self-injuring or injuring of other people and property can also be prevented in this way. For instance, a police 
officer can use their physical strength and binding to restrain the executive debtor who is trying to prevent listing of their movable property in order to sell it and settle the executive creditor's claims; a police officer can also use physical force and binding to make the executive debtor leave the real estate when they show resistance during the enforcement action of emptying and handing over the real estate, etc. The essence of the police assistance is for a police officer to use a coercion instrument at a time that achieves the goal of the police action with as few consequences to the person the coercion instrument is used on as possible.

\section{Responsibility of the Police and Costs of Providing the Police Assistance and Undertaking Police Actions}

The manager of the authorized organizational police unit is obliged to act according to the request of the public executive officer for the police assistance. As previously mentioned, if out of reasons noted in the submission they determine that conditions for providing police assistance have not been fulfilled, since it cannot be determined that during the enforcement action resistance will occur or that disturbance of public order or broader violence may be anticipated, the manager of the authorized organizational police unit will reject the public executive officer's request. However, not acting in accordance with the public executive officer's request represents a violation of duty. In this case the public executive officer informs the Ministry of Internal Affairs and the authorized prosecutor for the sake of undertaking a procedure for determining responsibility of the manager of the authorized organizational police unit. Then, rules on disciplinary responsibility are applied which are contained in the LP and in the Regulation on the Way of Implementation of the Disciplinary Procedure in the Ministry of Internal Affairs (Uredba o načinu..., 2017). According to the LP, police officers are held responsible for serious and minor violations of official duties and if they do not perform the police work conscientiously, professionally and in the planned deadlines (LP: art. $202-203$, par. 1). Not acting of the manager of the authorized organizational police unit according to the request of the public executive officer for the assistance during the enforcement action can be defined as a serious disciplinary violation - non-taking or insufficient taking of measures in their scope of authority for the security of people, property and entrusted items (LP: art. 207. par. 1. point 5), for which disciplinary measures are regulated by article 209 of the LP.

The police assistance during the enforcement action is not free of charge since the very action requires engaging human and material police resources and the consequent costs. Both the LP and LES define the rules concerning the cost of providing the police assistance. The LP only with a general regulation states that the fee for providing the police assistance during the enforcement action is defined in accordance with the regulations related to services provided by the Ministry of Internal Affairs (Art. 53, par. 2). On the other hand, the LES states more in detail the costs of the police assistance, noting that costs for providing the police assistance and undertaking police actions on the request or order of the court or public executive officer are: "costs of engaging police officers and usage of police vehicles and equipment" (Art. 147, par. 1) the amount of which is determined by the regulation for defining the reimbursement for services provided by the Ministry of Internal Affairs. The reimbursement for providing the police assistance and undertaking police actions is defined by the Regulation on Reimbursement for Services Provided by the Ministry of Internal Affairs (Uredba o visini..., 2014).

When the police assistance during the enforcement action is provided, the authorized organizational police unit calculates the costs of the police assistance and undertaking of police actions and delivers the bill to the public executive officer. The costs of the police assistance and undertaking police actions represent a part of the costs of the enforcement procedure and are to be paid to the account for payment of public revenues of the Republic of Serbia.

\section{Conclusion}

The police assistance during the enforcement action represents a very important issue to which a lot of attention has been devoted in legal regulations. However, in the literature of civil law there are neither scientific articles nor monograph studies concerning this topic.

The introduction of public executive officers into our legal system has been followed by entrusting the members of this legal profession with a lot of authorizations. Therefore, public executive officers are authorized to implement the enforcement in most of executive legal matters. 
However, besides great authorizations, public executive officers do not have the right to use physical force and that way fight the resistance during the enforcement action. When during the enforcement action some resistance or disturbance of public order or some broader violence is anticipated, the public executive officer has a right to address the police and request the police help during the enforcement action. The LP and LES undoubtedly regulate in detail the procedure for requesting the police assistance, define the contents of the claims of the public executive officer for providing the police assistance and norm in detail the rules concerning the police actions, costs of undertaking the police actions and possible responsibility of police officers for not acting according to the request of the public executive officer. In support of this conclusion a large number of regulations and rulebooks are added. These regulations and rulebooks comprehensively regulate the way of coercion implementation and the way of undertaking police actions in the area of providing assistance to the court or public executive officer during the enforcement action.

Regulating the issues related to providing the police assistance during the enforcement action is of large significance since situations in which resistance of executive debtors during the enforcement action is present are common. As the resistance of executive debtors or third parties has to be overcome, avoiding damage to human lives and property, disturbance of public order or broader violence, a general conclusion can be drawn that the police assistance according to predefined standards, in individual, delicate and hard life situations, is the only way to overcome a crisis and provide unhindered implementation of the enforcement action.

\section{References}

Boranijašević, 2017 - Boranijašević, V. (2017). Javnoizvršiteljsko pravo [Public-enforcement Law] (prvo izdanje). Kosovska Mitrovica: Pravni fakultet Univerziteta u Prištini sa privremenim sedištem u Kosovskoj Mitrovici.

Keča, Knežević, 2017 - Keča, R., Knežević S.M. (2017). Građansko procesno pravo [Civil Process Law], Priručnik za polaganje pravosudnog ispita, (trinaesto dopunjeno izdanje). Beograd: Službeni glasnik.

Kodeks policijske etike, 2017 - Kodeks policijske etike [The Code of the Police Ethics]. Službeni glasnik RS. Br. 17.2017.

Posilović et al., 2014 - Posilović, D., Mršić, Ž., Šantek, M. (2014). O nekim pitanjima pružanja policijske pomoći - asistencije [On Some Issues of Providing the Police Help Assistance]. Policija i sigurnost br. 2/2014, 105-128.

Pravilnik o načinu obavljanja..., 2007 - Pravilnik o načinu obavljanja policijskih poslova [The Rulebook on the Way of Conduct of the Police Affairs]. Službeni glasnik RS. Br. 27. 2007.

Pravilnik o tehničkim..., 2007 - Pravilnik o tehničkim obeležjima i načinu upotrebe sredstava prinude [The Rulebook on Technical Characteristics and the Way of Usage of Coercion Instruments]. Službeni glasnik RS. Br. 19. 2007, 112. 2008 i 115. 2014.

Stanković et al., 2018 - Stanković, G., Palačković, D., Trešnjev, A. (2018). Komentar Zakona o izvršenju i obezbeđenju [Comment on The Law on Enforcement and Security]. Beograd: Službeni glasnik.

Stanković, Boranijašević, 2017 - Stanković, G., Boranijašević, V. (2017). Pravo izvršenja i pravo obezbeđenja [The Law on Enforcemet and Security] (prvo izdanje). Kosovska Mitrovica : Pravni fakultet Univerziteta u Prištini sa privremenim sedištem u Kosovskoj Mitrovici.

Stanković, 2007 - Stanković, G. (2007). Građansko procesno pravo [Civil Process Law], druga sveska, Vanparnično i izvršno procesno pravo (sedmo izmenjeno i dopunjeno izdanje). Niš: Udruženje za građansko procesno i arbitražno pravo.

Uredba o načinu..., 2017 - Uredba o načinu sprovođenja disciplinskog postupka u Ministarstvu unutrašnjih poslova [The Regulation on the Way of Implementation of the Disciplinary Procedure in the Ministry of Internal Affairs]. Službeni glasnik RS. Br. 26. 2017.

Uredba o visini..., 2014 - Uredba o visini naknada za usluge koje pruža Ministarstvo unutrašnjih poslova [The Regulation on Reimbursement for Services Provided by the Ministry of Internal Affairs]. Službeni glasnik RS. Br. 126. 2014, 90. 2015.

Zakon o izvršenju i obezbeđenju, 2015 - Zakon o izvršenju i obezbeđenju [The Law on Enforcement and Security]. Službeni glasnik RS. Br. 106.2015, 106.2016 - autentično tumačenje i 113.2017 - autentično tumačenje. 
Zakon o izvršenju i obezbeđenju, 2011 - Zakon o izvršenju i obezbeđenju [The Law on Enforcement and Security]. Službeni glasnik RS. Br. 31.2011, 99.2011 - dr. zakon, 109.2013 odluka US, 55.2014 i 139.2014.

Zakon o parničnom postupku, 2011 - Zakon o parničnom postupku [The Law on Civil Proceedings of the Republic of Serbia]. Službeni glasnik RS. Br. 72.2011, 49.2013 - одлука УС, 74.2013 - одлука УС и 55.2014. 2016.

Zakon o policiji, 2016 - Zakon o policiji [The Law on the Police]. Službeni glasnik RS. Br. 6.

Да би спречиле... - „Да би спречиле исељење, мајка и ћерка напале полицију и извршитеље“. [Electronic resource]. URL: http://nadlanu.com/145930/da-bi-sprecile-iseljenjemajka-i-cerka-napale-policiju-i-izvrsitelje/.

Драма у Лебану... - „Драма у Лебану: Полио се бензином и чека извршитеља, око њега живи зид“. [Electronic resource]. URL: http://jugmedia.rs/drama-lebanu-polio-se-benzinomceka-izvrsitelja-oko-njega-zivi-zid/.

Ни полиција... - „Ни полиција није могла да га спречи: син дужника штанглом претукао извршитеља“. [Electronic resource]. URL: https://www.srbijadanas.net/ni-policijanije-mogla-da-ga-spreci-sin-duznika-stanglom-pretukao-izvrsitelja/. 